Jurnd PerddkanBatesacknSastra, V dume12, Nomor 2, Oktdber 2012

\title{
TRADISI LISAN MALE-MALE: NYANYIAN KEMATIAN DALAM MASYARAKAT CIACIA: KAJIAN SOSIOLOGIS DAN UPAYA PEWARISAN
}

\author{
Asrif \\ Balai Bahasa Provinsi Sulawesi Tenggara \\ Korespondensi: Perumnas Poasia, Blok D Nomor 46, Kota Kendari, Sulawesi Tenggara, \\ Pos-el: asrif_wakatobi@yahoo.co.id.
}

\begin{abstract}
Abstrak
Tradisi Lisan Male-Male: Nyayian Kematian dalam Masyarakat Ciacia: Kajian Sosiologis dan upaya Pewarisan. Male-Male merupakan syair yang dinyanyikan sesaat setelah seorang warga yang dianggap sosok sempurna meninggal dunia. Tradisi lisan ini menggambarkan penghargaan masyarakat terhadap sosok sempurna melalui ungkapan kesedihan, kerinduan, ketabahan, dan puji-pujian. Pelaksanaan Male-Male memiliki sejumlah fungsi, baik fungsi pribadi (penutur dan tuan rumah) maupun fungsi bagi masyarakat (warga yang melayat). Bagi penutur dan tuan rumah, tradisi ini berfungsi untuk menghibur, kepedulian sesama, penyebaran nilai-nilai sosial dan agama, prestise, dan mewariskan tradisi. Bagi masyarakat, Male-Male berfungsi sebagai sarana mengingatkan diri akan kematian, memperkokoh keimanan, dan meningkatkan empati, serta solidaritas sesama. Diperlukan upaya pewarisan dalam menjaga keberlanjutan tradisi ini. Pewamisan formal yakni melalui sekolah, sedangkan pewarisan informal melalui penguatan lembaga adat.
\end{abstract}

Kata kunci: Tradisi Lisan, Male-Male, Sosiologis, dan Pewarisan

\begin{abstract}
Oral Tradition of Male-Male: Death Anthem Ciacia: Sosiological Studies and an Effort to Pass It On to the next Generation. Male-Male is lyrics sung upon the death of a member of the society who is considered a perfect person. This oral tradition shows the society appreciation towards the person through the expression of sadness, longing, partience and praises. Male-Male serves various functions; both private functions (the singer and host), and societal function (the guests). For th singer and the host, this tradition serves as consolation, caring towards other members, dissemination of social values and religion, prestige, and passing on a tradition. For the society, Male-Male functions as a self remainder of death, strengthening faith, increasing empathy and solidarity. Efforts to guarantee the continuity of this tradition by the next generation are required. Formal effortcan be made through schools, and the informal ones can be made through the strengthening of tradition bodies.
\end{abstract}

Keywords: Oral tradition, Male-Male, Sociology, and Passing the tradition

p-ISSN 1412-0712 | e-ISSN 2527-8312 